\title{
Conclusion: "Ein Kern in der Frucht"
}

The true extent of the pessimism found in 1003 and Lazaretti oder Der Säbeltiger can only be appreciated with a full understanding of the importance of conscience throughout Hochwälder's work; as he makes clear in his essay, "Vom Versagen des Dramas in unserer Zeit", Gewissen is the one truly human characteristic". While here and in 1003, he expresses the fear that conscience may ultimately be sacrificed, along with humanity, and in Lazaretti oder Der Säbeltiger, even its relevance is openly questioned, the belief in the voice of conscience is not fully lost.

Indeed, throughout Hochwälder's work there remains a cautious faith in humanity, a belief that justice can, if only occasionally, be done, through the acceptance of individual moral responsibility. Combined with this is a faith that criminal behaviour will eventually be called to account and punished.

Such faith must always remain tentative, for Hochwälder was all too aware how easily humanity can be corrupted and inhumanity allowed to triumph, how human weakness and the desire to avoid the burden of conscience can aid and nurture evil.

Hochwälder's overriding concern with human behaviour is wholly understandable, for forced into exile to survive, he lost his family to the National Socialist Holocaust, an event which led him to become a writer of plays which sought to explain how such atrocities, committed by quite sane individuals, are possible. As James Schmitt observes:

\begin{abstract}
Almost all of Hochwälder's plays [...] mirror in some way scars from the war. According to his analysis, man's most grievous sin during the Nazi years, and indeed his foremost failing even today, is his lack of responsibility. Man easily sacrifices his autonomy for personal convenience or because of outward pressure. His irresponsibility is especially evident when he offers the excuse that he cannot be responsible because there is no justice in the world ${ }^{2}$.
\end{abstract}

Certainly, the societies presented in many of Hochwälder's plays suggest that naked self-interest may be the only way to survive, and financial success and social standing do little to ameliorate this trait, as testified by Paunzinger in "Der liebe Augustin", the ruling elite in Esther, the Spanish traders in Das heilige Experiment, and the supposedly respectable citizens of Hotel du Commerce and Die Herberge. Even in dramas where characters seem to have more than they could want in the way of wealth and success, such as

\footnotetext{
${ }^{1}$ Hochwälder, Im Wechsel der Zeit, 65.

2 Schmitt, "The Theme of Responsibility [...]", 24-25.
} 
Lutmer in "Kaufmann und Kuenstler" and Pomfrit in Donnerstag they remain dissatisfied and selfishly demand more, highlighting the fact that selfishness does not bring happiness. This very point is made most poetically in Hochwälder's late drama, Der verschwundene Mond, when Gustave learns to his cost that money cannot buy love. This most base of characteristics, selfishness, is also seen to play a considerable role in the mentality of those who supported National Socialism, and would do so again given the opportunity: mercenariness is nowhere more strongly shown in Hochwälder's work than by the old Nazis that inhabit Bad Brauning in Der Himbeerpfliicker.

Self-interest of a more understandable sort is also apparent in many dramas, for the desire for self-preservation may lead to individuals choosing to run, rather than confront evil, or attempt to hide from it behind orders. In doing so, however, they may contribute to that which they wish to avoid. Marie in "Der Prozess" and the refugees in "Casa Speranza" have attempted to put the horrors of the past behind them, only to find that they again must face them. Meier Helmbrecht, partly from fear, partly from the pressure of others, chooses not to discipline his unruly son, and tries to ignore the warning signs he sees all too clearly. The border guard in Der Flüchtling and Fouquier in Der öffentliche Ankläger both try to hide behind the defence that they are merely following orders, whereas they contribute far more to the inhumanity around them. Again, such justifications find their correlation in a play directly related to the Holocaust, for Mittermayer in Der Befehl must ultimately discover there can be no hiding behind orders, and that it is impossible to be a conscientious employee of an inhuman regime. Yet others around him show a disturbing ability to adjust to circumstances and blame the times rather than individuals.

Given the evil of which humans are capable, which is repeatedly demonstrated by Hochwälder, it is understandable to place one's faith in a higher order through which the world may be changed for a better place. But this too is exposed as a dangerous folly which may produce still greater evil. Mordechai in Esther and Agathon in Die Bürgschaft both put their faith in the state, although they know it to be corrupt, believing it is possible to change it from within, while de Miura in Das heilige Experiment is so loyal to the crown of Spain that he carries out orders he knows to be unjust. Likewise, in the Jesuit drama, the Provincial chooses to obey the orders of his church superiors instead of listening to his conscience. The risk of too great a reliance on any ideology is shown in Donadieu, through the struggles of the Titelheld and the experiences of Escambarlat, as well as the legacy of suffering brought about by religious conflict. Ideological fanaticism is also strongly challenged in Die Prinzessin von Chimay. The dangers of being drawn into evil by a belief that the greater good may be served are also evident in Der öffentliche Ankläger, where both Theresia and Montané consciously choose to commit crimes, and in Die Bürgschaft, where Heloris' hopes to transform society through violence. The perils of compromising with evil, even from the best of 
intentions, are also related to the Hitler years in the story of Victor Glaser, which unfolds in Holokaust.

The necessity of being able to take individual responsibility is also highlighted in other ways. The characters of several plays find themselves in extremely difficult positions in which they have no one to rely on but themselves. In other dramas it is shown how impossible it is to really know another, and of what others are capable, emphasizing the fact that the individual alone can take responsibility for his or her behaviour. The father in "Jehr", the parents in "Trommler" and the protagonist of "Virginia" all find themselves in unenviable positions with no one to turn to for advice, and without the personal resolve to do what is right, each play ends in tragedy. Likewise, in the plays Die unziemliche Neugier, "Die verschleierte Frau", Der Unschuldige, and Der Befehl [stage version] even married couples show themselves to be fundamentally ignorant of one another. In Die Prinzessin von Chimay the monster Teresa seeks is revealed as her trusted advisor, Maergesse.

Yet, while the difficulties of and obstacles to taking personal responsibility are all too evident in play after play, in most there is a glimmer of optimism which points to alternative courses of action and advocates the acceptance of the dictates of conscience.

In its most obvious form this is represented by minor characters, more often than not female and, alas, wooden and one-dimensional. The first of these is Marie in the early drama, "Der liebe Augustin", who shows compassion and moral outrage at events around her, and chooses to marry the good, if perhaps easily led, Dr. Genz, so that together they may build a better future, based on the belief that: "Was Menschen trifft, kann auch von Menschen abgewendet werden!" (DLA, 28). Marie is followed by Lilli in "Casa Speranza", the first of three female figures to have restrictive relationships with older men. She, like her successors, must reject the dictates of her companion, here the resignation and pessimism of Faden, and break free to express a faith in humanity. Despite the suicide of Faden, she, having insisted on optimism throughout the play, stands by the fugitive, Frühberg, for: "Den Toten nuitzt keine Hilfe - den Lebenden muss man helfen..." (CS, 72). The two Rouzha's are in much the same role. The first, in Holokaust, is initially tied to Roberts. However, when she recognizes that he is only seeking meaning to his own existence, rather than justice (Holokaust, 83), she rejects him, and in her compassion accepts responsibility for Glaser's death at the end (Holokaust, 91) ${ }^{3}$. Her namesake in Lazaretti oder Der Säbeltiger, also breaks with the misguided men around her, Camenisch and the younger Dr. Fliess, to save her humanity in the face of their murderous intrigues (III, 296).

In addition to these unconvincing characters, those of Estrella and Burgerl, in Donnerstag and Der Himbeerpflücker respectively, might be added. However, in defence of these figures it should be stressed that Estrella, is a type

${ }^{3}$ Fittingly it is another decent, minor female character, Mme. Singer, who insists that hope be maintained despite all the suffering: "Wir müssen hoffen. [...] Anders verdienen wir nicht zu leben" ("Holokaust", 82). 
quite in keeping with the Jedermann tradition, representative of the human love missing in Pomfrit's life, whereas Burgerl, with a gruff, matter-of-fact good nature and common-sense compassion toward Kerz, more than convinces as a Volksstück figure.

Indeed, it is rather ironic that the only other decent character in Der Himbeerpflücker is the petty thief, Kerz, who is incapable of inflicting violence on another human and who is horrified when he learns he has been mistaken for a mass murderer. An analogous dramatic device is used in Hôtel du Commerce, where it is the prostitute, Elisabeth, who through generosity and laudable patriotism highlights the inadequacies of the others. In both plays it is characters who might normally by expected to be beyond the bounds of "decent" society who demonstrate the moral sensibilities that are the prerequisites for genuine decency.

Often, even in the bleakest plays, where characters continue to act unethically, they nonetheless must do so consciously, for an alternative is always presented. The parents in "Trommler" are, for example, well aware that what they are doing is wrong, yet the mother through her determination and the father through his weakness, allow the tragedy to unfold. The king in Esther is plagued by his conscience $(I, 66)$, yet at the end of the play, having survived, along with the Jewish people, by chance rather by judgment, quite consciously chooses to commit further crimes to preserve his position $(I, 81)$. In "Virginia" an alternative to the measures the protagonist takes to survive a brutal environment is presented, albeit off-stage, by Francisco, who has managed to make his way in the world without sacrificing his principles ("Virginia", 72). Virginia's choice, however, will clearly lead to her own destruction. Fouquier-Tinville has a moment of enlightenment into the horror of his world, when he looks out on the blood-red Seine (I, 307-308), even if he does not heed it, and it is he who issues warnings to both Theresia and Montané (I, 305, 325), both of whom knowingly commit crimes (I, 269-270, 303). Even the two plays which most seem to call into question the continuing role of conscience, demonstrate alternatives to immorality, or amorality: the Nichtmensch in 1003 is confronted by the Mensch, Valmont, admittedly with all his very human weaknesses; and Camenisch in Lazaretti oder Der Säbeltiger, is aware he is doing wrong, as shown both by his admission to Fliess (III, 282), and by his hesitation at the end, before stealing his friend's work (III, 296-298).

When characters fail to heed the voice of conscience, and continue to act in ways they know to be immoral, the results are often disastrous and selfdestructive: the parents in "Trommler" destroy that which they seek; Virginia and Fouquier-Tinville conspire to bring about their own downfall by actions designed to secure their futures; and Gustave, in hoping to buy happiness, destroys that which makes love possible (IV, 74).

That those guilty of wrongdoing continually fall victim to their own unethical machinations is in keeping with a belief in the inescapability of personal responsibility. Hochwälder outlines this in regard to two central plays in his 
essay, "Über mein Theater":

[...] Der Haupt- und Staatsaktion im dialektischen Experiment entspricht das symbolische Geschehen in der Herberge: Gewiß ist unsere Welt von himmelschreiendem Unrecht erfüllt, ebenso gewiß aber wird jedem in der Stunde der Abrechnung, was er sich im Lauf seines Lebens selbst zugemessen. Die Moral: Wem es vergönnt ist, seine Erdentage in äußerer Freiheit zu beschließen, dem erwächst höhere Gerechtigkeit aus allem Unrecht, das er verschuldete, und diese Schuld in der eigene Brust nimmt uns kein Idealstaat $a b^{4}$.

Regarding Die Herberge, described by Hochwälder as "mein wertvollstes Stiick", this is elevated to the plain of metaphysics: "Die Philosophie die ausgesprochen wird, ist nicht ganz einfach. Sie heißt, auf einen Nenner gebracht: Persönliche Schuld rächt sich wieder durch die Schuld selbst"5.

But, if Berullis is called to account in Die Herberge by falling victim to the crime of theft, which he himself had committed years earlier, and if Andusz is caught for a murder by being tempted again, it is a turn of events that occurs in many plays. Fouquier-Tinville is framed and delivered to the guillotine, like so many of his victims in Der öffentliche Ankläger. Likewise, Degenhart has the tables reversed on him in "Der Prozess", when Marie destroys him as he once hoped to destroy her. In the television version of Der Befehl, Mittermayer falls victim to the apparition of the man he once was, and, like his earlier victim, drowns in a canal, while in Der Flüchtling and Donadieu the Grenzwächter and du Bosc pay for their crimes in the manner they had planned for their adversaries.

In other plays, punishment may not be at issue, or appropriate, but nevertheless characters are brought to confront their actions. Meier Helmbrecht is forced to face his failed responsibilities, but has suffered enough not to suffer further punishment, unlike his son. Glaser in Holokaust is driven by torment for his involvement in Hitler's genocide to confess his role and seek release from his conscience. Maergesse, and to a lesser extent, Teresa, in Die Prinzessin von Chimay, must confront a past thought long buried and their own dubious roles in it.

Even Lazaretti oder Der Säbeltiger, which with its introduction of a fatalistic theory of evolution threatens to undermine the validity of conscience, propounds the rather Christian notion that they who live by the sword shall die by it; Lazaretti's dangerous manuscript spells it out:

[...] fast alle Verfolger früher oder später [teilen] das Schicksal der von ihnen Verfolgten. Demnach: langfristig herrscht Gerechtigkeit. [...] Leo

4 Hochwälder, Im Wechsel der Zeit, 86.

5 A. M., "Das Herz ist lauter als Kanonendonner", GONG, Funk-Fernsehwelt [Ausgabe Berlin], Nr. 12, 1970, 95 . 
Trotzki, genialer Schriftsteller und Schlächter der Matrosen von Kronstadt, stirbt in Mexico unter der Spitzhacke eines fanatischen Agenten. - Fazit: Verdientes Ende eines intellektuellen Bluthundes .[...] Fouquier-Tinville, Staatsanwalt des Terrors in der Französischen Revolution, besteigt als einer der letzten das Schafott. - Und so weiter und so weiter, bis zu den gelehrigen Schülern im 20. Jahrhundert, den Dscherschinskis, Jeschows, Jagodas und Freislers... General Oufkir zuletzt, der Marokkaner, Mörder des Ben Barka - Selbstmord angeblich, nach mißlungenem Putsch

(III, 261-262)

Lazaretti's name might well be appended to the list, for he falls victim to a campaign of terror like that he advocates in his book should be conducted against terrorists. Unfortunately, a rather more long-term view of history, based on the fate of a prehistoric mammal later confuses things [see Chapter 7].

But the importance of conscience in Hochwälder's work is not merely confined to what might be seen as a quasi-religious belief in a day of judgement; it is the very basis upon which justice and a more humane world may be built. It is in light of this that the true extent of the pessimism inherent in 1003 must be seen. For if the Nichtmenschen are already within society, and the end of the play and Hochwälder's views on the mentality that allowed the Holocaust ${ }^{6}$ would indicate that he believed they were, then their triumph, the widespread voluntary sacrifice of Gewissen would render obsolete notions such as Schuld and Gerechtigkeit, and with them would disappear humanity.

Yet although in 1003, Valmont cannot defeat Bloner, he still can choose whether to join him in a soulless existence. Unlikely though this refusal might seem, humanity still exists. It is upon this that the hope in Hochwälder's plays rests, for repeatedly characters come to accept personal responsibility for their actions, and learn to listen to the voice of their consciences. In some cases, this can prove the foundation for building a better future, in others characters can but atone for their behaviour with their lives, based on the belated acceptance of right and wrong.

Frequently this recognition comes in what George Wellwarth has termed an "inner revelation"?. In extreme situations individuals must face the truth about themselves and their behaviour, understanding what they must do, or admitting to the guilt they have incurred.

Confronted by her worst fear of meeting Degenhart again in "Der Prozess", and then learning that another has fallen victim to him, Marie sees it is her moral duty to stop him destroying others (DP, 51). Esther in the play of the same name, eventually turns her back on a life of privilege and luxury, having earlier felt no connection with her own people (I, 64-65), because she has come to realize that she cannot partake of a corrupt and unjust lifestyle (I, 81).

${ }^{6}$ Cf. Hochwälder, Im Wechsel der Zeit, 65-69.

${ }^{7}$ Wellwarth, "Fritz Hochwälder. The Drama within the self", 214. 
The inner voice of conscience is far more explicit in the words of the Provincial and de Miura in the last act of Das heilige Experiment. In pardoning Oros, the Jesuit leader recognizes his own guilt, testified to by "die Stimme des Widersachers in meiner Brust" (I, 139), and having himself confessed his sins can find some hope with his dying breath. This inner voice is clearly contagious, infecting his opponent, Miura: "Und doch - ist in meinem Herzen... etwas... das spricht [...] 'Was hülfe es, wenn ich die ganze Welt gewönne, und nähme doch Schaden an meiner Seele...' [...] auch diese Stimme ist in meinem Herzen $[. .$.$] "' (\mathrm{I}, 140)^{8}$.

Such repentance can also be found in the melodramatic end of Der Flüchtling, where the border guard finally acknowledges his own role in an inhumane system, atoning with his life so that his wife and the fugitive might escape (I, 119-120).

A similar fatal recognition of personal guilt occurs in the final [stage] version of Der Befehl. Mittermayer's voyage of self-discovery finally leads to him taking responsibility for his actions and rejecting the mitigation proffered by Dwornik that the times were to blame (II, 331) ${ }^{9}$. Like the Grenzwächter before him, Mittermayer has recognized that his entire life, founded on the belief that it was honourable to follow orders, has been based on selfdeception.

The confession of guilt that is extracted from Meier Helmbrecht (I, 244) leads to a slightly more positive conclusion, for based upon an admission of the truth he can begin to rebuild (I, 248). The Erzpoet, on the other hand, still fails to accept any personal responsibility and therefore justly receives a beating from the wiser Helmbrecht (I, 247).

True justice, as opposed to bloody vengeance, can only be achieved in Donadieu when the protagonist overcomes his personal desires for revenge and recognizes he must act for the greater good. The judgment passed by Lavalette on du Bosc is explained in words designed to have much wider ramifications: "Recht tun heißt: sich reinigen vom eignen Bösen" (II, 62).

Nowhere is this insistence on the inner voice of conscience as the only basis for justice made clearer than in Hochwälder's Herberge. It is this inner voice to which even Berullis must momentarily listen (II, 132), and its importance is emphasized by Schimke's reply to the cynical Smalejus' question:

SMALEJUS: Was - war?

SCHIMKE: Gerechtigkeit.

SMALEJUS: Wo ist Gerechtigkeit?

SCHIMKE: In unserer Brust, Herr. Mitten im Unrecht wohnt Gottes Ge-

8 Despite the tragic end of the Jesuits' work in Paraguay, the play still holds out the promise of justice being achieved in the end, through Comelis' prediction, full of dramatic irony for any audience that knows its history, that the Dutch will soon take over Spain's empire, for they shall fall victim to their own crimes: "Und wie ihr gekommen seid in Blut, so erstickt ihr langsam in Blut..." (1, 137).

9 To these last two plays can be added Der verschwundene Mond, in which Gustave atones for his crime with death, and as a result the moon returns to the sky. 
The significance of these words to Hochwälder's work cannot be underestimated; the last sentence is inscribed on the dramatist's gravestone in Vienna. The basis for hope throughout Hochwälder's dramas is based on the need for an acceptance of personal responsibility, the need to look within oneself to conquer the evil within, and to fight and resist evil from without. Although it may be tempting to avoid this responsibility, ultimately nothing, no higher authority or state can absolve one from it, nor can one turn to others, for no one can truly know what lies within another. In extreme situations one is alone with one's conscience and must choose whether to follow its dictates.

Hochwälder recognises just how heavy this burden is, how for numerous reasons the individual may choose to ignore the inner voice, may gratefully sacrifice it for a life of empty pleasure such as that led by the Nichtmenschen Bloner. However, justice and fulfilment can only come from within, and any other path may lead to self-destruction or allow for the monstrous inhumanity of the French Revolution's Terror or the Nazi Holocaust. It is the failure to take personal responsibility and to refuse to become embroiled in evil that allows it to thrive.

Yet heavy though this burden may be, it also provides us with hope for the future, as is made clear not just by the mystical Schimke but by his fellow mystic traveller, Kapora to the despairing Pomfrit: "Niemand, keine Gewalt, keine Macht kann Ihnen verleihn, was unerweckt in Ihrer Brust schläft: Glaube, Liebe, Hoffnung..." (III, 163), for "Der Glaube kommt aus dem Nichts [...] und ist nicht auch die Schöpfung aus dem Nichts erstanden?" (III, 198).

Hochwälder steadfastly rejected any religious interpretations of his work ${ }^{10}$, and several of his plays highlight the potential dangers of religious or ideological beliefs, but was prepared to make one small concession in a letter to James Schmitt:

Über die Theodizee meiner Stücke - - sofern eine solche darin enthalten ist - - kann ich nicht viel sagen, schliesslich kommt es drauf an, was der Zuschauer oder Leser empfindet. Jedenfalls scheint es mir heute, da ich die Sechzig überschritten habe, mehr denn je als richtig, dass der Mensch, nach Vererbung und Charakter, sein eigenes Schicksal darstellt und für seine Taten voll verantwortlich ist ${ }^{11}$.

10 Cf. Hochwälder, Im Wechsel der Zeit, 89. His lack of religious convictions is made quite clear when describing the hospitality he received at a monastery where he sought solitude to write:

Im Kloster war es herrlich, die hiesigen Mönche samt Abt sind, da noch dazu Benediktiner, unglaublich tolerant und beherbergen hartnäckig Jahr für Jahr einen Juden, dessen profunde Glaubenslosigkeit ihnen bekannt ist, der Gast ward noch nie in der Kirche gesehen, ebensowenig allerdings in der Zürcher Synagoge.

- Fritz Hochwälder, Brief an Ernst Waldinger, 14. Aug. 1965, Dokumentationsstelle für neuere österreichische Literatur, Wien.

11 Fritz Hochwälder, letter to the James Schmitt, April 12, 1972, quoted in: Schmitt, "The 
This concept of personal responsibility need not be so qualified, for as the basis for ethical behaviour it remains a constant throughout Hochwälder's work. In his own words he was "ein verdammter Moralist", who recognized that justice and morality are present in the human make-up, albeit all too often well hidden, like the stone at the centre of fruit.

Theme of Responsibility [...]", 38 . 